\title{
Initial ACTR Retrieval Technology \\ Evaluation Test Material \\ Recommendations
}

\author{
M. R. Powell
}

April 1996

Prepared for the U.S. Department of Energy under Contract DE-AC06-76RLO 1830

Pacific Northwest National Laboratory Operated for the U.S. Department of Energy by Battelle 


\section{DISCLAIMER}

This report was prepared as an account of work sponsored by an agency of the United States Government. Neither the United States Government nor any àgency thereof, nor Battelle Mernorial Institute, nor any of their employees, makes any warranty, expressed or implied, or assumes any legal liability or responsibility for the accuracy, completeness, or usefulness of any information, apparatus, product, or process disclosed, or represents that its use would not infringe privately owned rights. Reference herein to any specific commercial projuct, process, or service by trade name, trademark, manufacturer, or otherwise does not necessarily constitúte or imply its endorsement, recommendation, or favoring by the United States Government or any agency thereof, or Battelle Memorial Institute. The views and opinions of authors expressed herein do not necessarily state or reflect those of the United States Government or any agency thereof.

\section{PACIFIC NORTHWEST NATIONAL LABORATORY operated by \\ 'BATTELLE \\ for the \\ UNITED STATES DEPARTMENT OF ENERGY \\ under Contract.DE-AC06-76RLO 1830}

Printed in the United States of America

Available to DOE and DOE contractors from the

Office of Scientific and Technical Information, P.O. Box 62, Oak Ridge, TN 3783T; prices available from (615) 576-8401.

Available to the public from the National Technical Information Service, U.S. Department of Commerce, 5285 Port Royal Rd., Springfield, VA 22161

This document was printed on recycled paper. 


\title{
Initial ACTR Retrieval Technology Evaluation Test Material Recommendations
}

\author{
M. R. Powell
}

April 1996

Prepared for the U.S. Department of Energy under Contract DE-AC06-76RLO 1830

Pacific Northwest National Laboratory

Richland, Washington 99352 



\section{Summary}

Millions of gallons of radioactive waste are contained in underground storage tanks on the U.S. Department of Energy's Hanford Site in southeastern Washington State. Techniques for retrieving much of this waste from the storage tanks have been developed. The current baseline waste-retrieval approach is to use sluice jets for single-shell tanks and mixer pumps for double-shell tanks. The Acquire Commercial Technology for Retrieval (ACTR) effort was initiated to identify potential improvements in or alternatives to the baseline waste-retrieval methods. Communications with a variety of vendors are underway to identify improved waste-retrieval methods that can be implemented at Hanford with little or no additional development. The commercially available retrieval methods will be evaluated by a combination of testing and system-level cost estimation.

Waste simulants are needed to support the testing of candidate retrieval technologies through ACTR. An effort is underway to identify and specify waste simulants that will meet the needs of ACTR. The current progress toward this goal is documented in this report. Test materials designed to be similar to tank waste in certain key respects are described herein.

The specified simulants are designed to model four different types of tank waste. Simulant recipes are given for wet sludge, hardpan/dried sludge, hard saltcake, and soft saltcake. The specified simulants are made from relatively inexpensive, non-hazardous materials that present no unusual disposal problems.

Comparisons of the relevant waste and simulant properties are documented in this report. These comparisons provide the justification for the properties of the specified simulants. In most cases, the simulants are shown to be reasonably similar to the known and estimated waste properties in the relevant respects. The specified simulants, however, cannot be considered validated based on the information presently available. More waste characterization data and retrieval process test data are needed to improve the confidence in these simulants. 



\section{Contents}

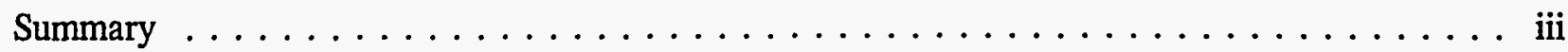

1.0 Introduction $\ldots \ldots \ldots \ldots \ldots \ldots \ldots \ldots \ldots \ldots \ldots \ldots \ldots \ldots \ldots$

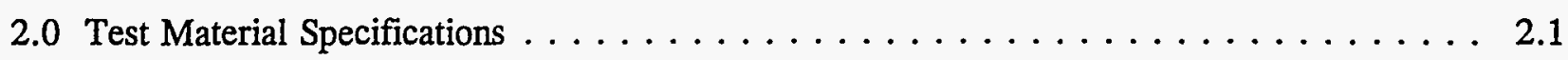

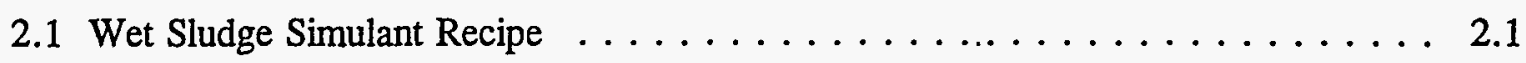

2.2 Hardpan/Dried Sludge Simulants (Two Recipes) $\ldots \ldots \ldots \ldots \ldots \ldots \ldots$

2.3 Saltcake Simulants (Five Recipes) $\ldots \ldots \ldots \ldots \ldots \ldots \ldots \ldots \ldots \ldots \ldots \ldots$

3.0 Test Material Selection and Defensibility $\ldots \ldots \ldots \ldots \ldots \ldots \ldots \ldots \ldots \ldots \ldots \ldots$

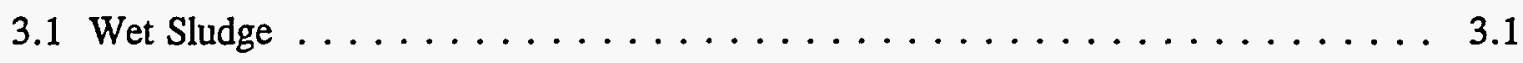

3.1.1 Relevant Properties for Wet Sludge $\ldots \ldots \ldots \ldots \ldots . \ldots \ldots$

3.1.2 Simulant and Waste Property Comparison . . . . . . . . . . 3.2

3.2 Hardpan/Dried Sludge $\ldots \ldots \ldots \ldots \ldots \ldots \ldots \ldots \ldots \ldots \ldots$

3.2.1 Relevant Properties for Hardpan/Dried Sludge . . . . . . . . . . . 3.7

3.2.2 Simulant and Waste Property Comparison . . . . . . . . . . 3.7

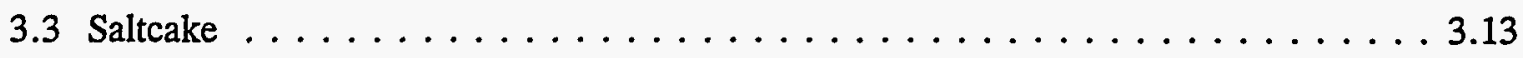

3.3.1 Relevant Properties for Saltcake Retrieval . . . . . . . . . 3.13

3.3.2 Simulant and Waste Property Comparison . . . . . . . . . . 3.14

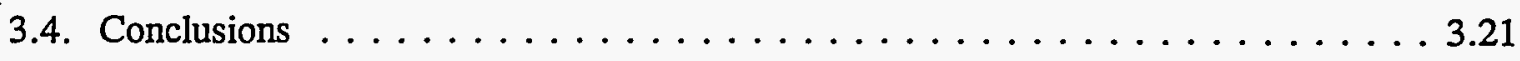

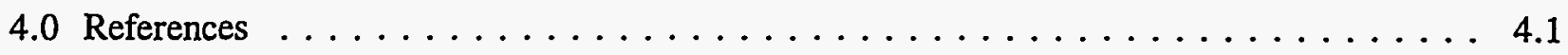




\section{Figures}

Figure 3.1. Particle Size Distribution: NCAW Core Sample $\# 2 \ldots \ldots \ldots \ldots$

Figure 3.2. Particle Size Distribution: Kaolin Clay (Brinkmann Sample 93-01413) $\ldots \ldots$. . . 3.3

Figure 3.3. Plot Showing Range of Wet Sludge Shear Strengths. $\ldots \ldots \ldots \ldots \ldots$

Figure 3.4. Histogram of Sludge Sample Densities. Data taken from Willingham (1994). . . . 3.6

Figure 3.5. Eroding Sluice Jet Pressure vs. Shear Strength for Kaolin/Plaster Simulants $\ldots \ldots$. 3.8

Figure 3.6. Shear Strength vs. Time for Hardpan Simulant $\# 2 \ldots \ldots \ldots \ldots \ldots$

Figure 3.7. Photograph of Chalk Shear Strength Tester $\ldots \ldots \ldots \ldots \ldots \ldots$

Figure 3.8. Compressive Strength of Salt/Plaster Simulants $\ldots \ldots \ldots \ldots \ldots \ldots$

\section{Tables}

Table 3.1. Salt Dissolution Times in Water . . . . . . . . . . . . . 3.19

Table 3.2. Salt Dissolution Times vs. $\mathrm{NaOH}$ concentration $\ldots \ldots \ldots \ldots \ldots \ldots \ldots$ 


\subsection{Introduction}

Millions of gallons radioactive waste are currently stored in underground storage tanks at the Hanford Site in southeastern Washington State. The waste was generated by decades of nuclear materials processing, primarily for defense purposes. The rheological and mechanical properties of the tank wastes vary considerably, depending on the waste chemistry and tank conditions (e.g., humidity and temperature). Some waste consists of viscous liquids; some is sticky, paste-like sludge; and some is hard saltcake.

It has been decided that much of this waste must be retrieved from the tanks and processed to create immobilized wasteforms suitable for long-term storage. Methods for removing waste from the tanks have been identified and developed for the purpose of generating baseline schedule and cost estimates for waste retrieval. The current baseline waste-retrieval approach is to use sluice jets for single-shell tanks and mixer pumps for double-shell tanks. There remains a group of single-shell tanks that may not be amenable to sluicing. This group includes those tanks containing difficult-toretrieve wastes and those that cannot be sluiced because of known or suspected leaks.

The Acquire Commercial Technology for Retrieval (ACTR) effort was initiated to help address the apparent shortfalls of the baseline waste retrieval methods. Communications with a variety of vendors are underway to identify improved waste-retrieval methods that can be implemented at Hanford with little or no additional development. The commercially available retrieval methods will be evaluated by a combination of testing and system-level cost estimation.

Waste simulants are needed to support the testing of candidate retrieval technologies through ACTR. An effort is underway to identify and specify materials that will meet the needs of ACTR. The current progress toward this goal is documented in this report. Test materials designed to be similar to tank waste in certain key respects are described herein.

One of the principal goals of ACTR is to compare various commercially available retrieval methods with the baseline Hanford waste-retrieval methods (e.g., sluicing for single-shell tanks). Those technologies that represent improvements over the baseline methods will be recommended for further consideration. To help perform this assessment, tests of each proposed method will be conducted in which the methods will be applied to a variety of simulated waste materials.

Of course, it would be ideal if these test materials were identical, in all relevant aspects, to the actual tank waste. This is not possible at this time, for several reasons. First, there is not adequate characterization of the physical properties of Hanford tank waste for accurate waste simulants to be designed. Second, the physical and chemical properties that determine process performance are not known for all of the commercially available retrieval methods. Third, even if the key waste properties were known and the magnitudes of those properties had been measured on waste samples, it is probable that matching all of the relevant properties exactly would require the use of hazardous materials. Because retrieval methods need to be tested at a fairly large scale, the expense of working with and subsequently disposing such hazardous materials could easily consume the majority of the testing budget (and may prevent testing altogether). 
It is recognized by ACTR that it is not yet possible to formulate waste simulants that are guaranteed to mimic the full range of tank waste properties exactly. This does not mean, however, that there is no value in proceeding with the testing of commercially available retrieval methods. It is possible to compare all the proposed technologies with each other and the baseline-retrieval methods using less-than-perfect waste simulants. The result of such testing is a ranking of the proposed technologies (including baseline methods). The test data might not permit the accurate prediction of waste-retrieval rates (like testing with "ideal" simulants would), but the methods can be ranked from best to worst provided that two conditions are met. First, it is necessary to ensure that the physical and chemical mechanisms that determine retrieval-system performance in the waste are similar to those in the waste simulants selected for testing. Second, the magnitudes of the relevant properties in the simulants need to cover a representative range of those of the tank waste.

Ensuring that the same mechanisms are at work in both the simulants and in the tank waste is difficult and may require an iterative approach to simulant development and testing, depending on the complexity of the waste-retrieval process. It is often necessary to design the first-generation simulants based solely on a consideration of the mechanisms that are likely to be involved and a review of the relevant literature (if any). These first simulants are then tested against the process in question to determine whether all observed performance can be attributed to variations in the selected key simulant properties. If not, then it is clear that additional or alternative properties must be considered and more simulant development is required (followed by more testing).

Determining whether or not the simulant properties cover the range of those same properties in the tank waste is accomplished through a combination of waste sample characterization, reviews of the properties of related materials, and a consideration of the relevant physical and chemical mechanisms.

The approach being used to develop simulants for ACTR follows these guidelines. A consideration of the types of retrieval methods being evaluated and data from related testing (conducted previously) was used to formulate the simulants described in this report. Efforts were made to make these simulants satisfy the two criteria described above, but more work is needed. The biggest obstacle is the lack of waste characterization data. This problem will not be resolved in the near future. The present need to perform retrieval-system evaluations necessitates the acceptance of some uncertainty with respect to waste properties.

The ACTR testing is needed both to compare candidate retrieval methods and to improve future simulant-based testing. The data from the ACTR testing will help determine whether the physical and chemical properties selected as the "key" properties for each technology are correct. It is expected that some changes to the simulants specified in this report will be recommended, based on what is learned from the first round of testing.

In this report, the terms "test materials" and "simulants" are used interchangeably. Simulants are materials that are designed to behave like tank waste in certain key ways. The primary purpose of simulants is to allow the testing of retrieval technologies for the purpose of predicting retrieval-system performance in the waste tanks. The primary purpose of a test material is to compare various proposed retrieval technologies to determine which are the best. According to these definitions, the recipes provided in Section 2.0 for ACTR are test materials. It is also necessary, however, that these 
test materials be simulants. The purpose of the ACTR testing is to identify the best retrieval methods for tank waste. The test materials, then, must be similar enough to the waste so that the retrieval methods that work best on the test materials will also work best on the waste. 



\subsection{Test Material Specifications}

The test materials recommended for testing by ACTR are described in this section. Three general types of tank waste simulants are specified below. These types are: (1) wet sludge;

(2) hardpan/dried sludge; and (3) saltcake. These different waste types are present in varying amounts . in the Hanford storage tanks. The composition and preparation instructions for each test material are given below. A discussion of the technical basis for each mixture is described in Section 3.0 of this report.

\subsection{Wet Sludge Simulant Recipe}

Composition:

$66 \%$ wt EPK Pulverized Kaolin Clay

$34 \%$ wt Water

Supplier:

EPK Pulverized Kaolin clay can be obtained in $50 \mathrm{lb}$ sacks from Feldspar Corporation (Edgar, Florida). (904) 481-2421

Preparation:

Mix the water and kaolin using a mixer designed for sticky pastes. Typical impeller-based mixers will not be adequate. Mixing should continue until a smooth consistency is obtained.

Properties:

The mixed paste is very sticky and has a shear strength of approximately $3.5 \mathrm{kPa}(0.51 \mathrm{psi})$. For comparison, creamy peanut butter has a shear strength of about $2.0 \mathrm{kPa}(0.3 \mathrm{psi})$. The physical properties of the mixed kaolin clay are largely independent of temperature over the range of $15^{\circ}$ to $80^{\circ} \mathrm{C}\left(59^{\circ}\right.$ to $\left.176^{\circ} \mathrm{F}\right)$, but freezing temperatures must be avoided. No cure time is associated with this material. It may be used immediately after preparation. If it is to be stored, care should be taken to prevent evaporation. The bulk density of this simulant is $1.65 \pm 0.03 \mathrm{~g} / \mathrm{cm}^{3}$.

\subsection{Hardpan/Dried Sludge Simulants (Two Recipes)}

Composition \#1:

$30.0 \%$ wt Plaster of Paris

27.5\% wt EPK Pulverized Kaolin Clay

$42.5 \%$ wt Water 
Composition \#2:

40.0\% wt Plaster of Paris

$22.5 \%$ wt EPK Pulverized Kaolin Clay

$37.5 \%$ wt Water

Suppliers:

EPK Pulverized Kaolin clay can be obtained in $50 \mathrm{lb}$ sacks from Feldspar Corporation (Edgar, Florida). (904) 481-2421

The plaster of paris used for development of this recipe is manufactured by DAP, Inc. of Dayton, Ohio and sold in $25 \mathrm{lb}$ bags under the trade name "Durabond Plaster of Paris."

Preparation:

Mix the water and kaolin until no more lumps are apparent. The consistency of this mixture will be similar to that of a thin milk shake. Add the plaster while mixing and mix only until a smooth consistency is once again observed. The viscosity of this mixture will be similar to that of a thick milk shake (composition $\# 1$ is slightly less viscous). At room temperature (about $20^{\circ} \mathrm{C}$ ) the mixture must be cast into the test fixture mold within about 15 minutes of adding the plaster of paris. At higher temperatures, even less time is available. It is recommended that a rotating drum mixer (typically used for concrete mixing) be used to prepare this simulant. These simulants cure to maximum strength in about 2-3 hours, and then the strength decreases by about $20-25 \%$. It is recommended that this simulant be allowed to cure for at least 16 hours.

Properties:

Composition \#1 reaches a peak shear strength of about $40 \mathrm{kPa}(5.8 \mathrm{psi})$ after several hours of curing. This strength then decreases over a $5-10$ hour period to a stable value of about $32 \mathrm{kPa}$ (4.6 psi). Similarly, composition \#2 reaches a peak strength of about $200 \mathrm{kPa}(30 \mathrm{psi})$ and a final strength of about $150 \mathrm{kPa}(22 \mathrm{psi})$. Heat is released by the plaster of paris hydration reaction. After the recommended cure time $(16 \mathrm{~h})$, the test materials may be used or stored. Long-term storage of these materials has not yet been evaluated, but it is expected that the properties will be stable provided that water evaporation is avoided. The density of simulant composition $\# 1$ is $1.48 \pm 0.05 \mathrm{~g} / \mathrm{cm}^{3}$ and that of composition \#2 is $1.65 \pm 0.05 \mathrm{~g} / \mathrm{cm}^{3}$.

\subsection{Saltcake Simulants (Five Recipes)}

Composition \#1:

$84 \%$ wt Potassium Magnesium Sulfate (Dynamate) Fertilizer

$16 \%$ wt Water 


\section{Composition \#2:}

$88 \%$ wt Potassium Magnesium Sulfate (Dynamate) Fertilizer

$12 \%$ wt Water

\section{Composition \#3:}

75\% wt Potassium Magnesium Sulfate (Dynamate) Fertilizer

$25 \%$ wt Water

\section{Composition \#4:}

$86.0 \%$ wt Sodium Chloride Rock Salt

9.33\% wt Plaster of Paris

$4.67 \%$ wt Water

Composition \#5:

95.0\% wt Sodium Chloride Rock Salt

$3.33 \%$ wt Plaster of Paris

$1.67 \%$ wt Water

Suppliers:

Potassium Magnesium Sulfate ("K-Mag") is distributed under the trade name "Dynamate" by James Farrel (Pacific Northwest Dynamate agent) who can be reached at (206) 623-1993.

The plaster of paris used for development of this recipe is manufactured by DAP, Inc. of Dayton Ohio and sold in $25 \mathrm{lb}$ bags under the trade name "Durabond Plaster of Paris."

Sodium chloride rock salt is obtained in $40 \mathrm{lb}$ bags from Morton International, Inc. under the trade name "Extra Coarse White Crystal Solar Salt."

Preparation:

The K-Mag test materials (compositions 1, 2, and 3) are prepared by mixing the Dynamate and water in the specified ratio in a low-shear blender or mixer (a concrete mixer is suitable). The resulting slurry is transferred into the test fixture mold and allowed to cure for 14 days. The test material should be covered to prevent water loss during curing. It may be necessary to use a concrete vibrator to remove entrained air bubbles from the slurry, once it is placed in the curing mold. If this is done, care should be taken to operate the vibrator only briefly (i.e., about 1 second at a time) to avoid particle size segregation.

The salt/plaster test materials (compositions 4 and 5) are prepared by first mixing the plaster of paris and water to a smooth consistency and then mixing in the rock salt. Mixing the salt with the plaster paste should be done in a rotating drum mixer (concrete mixer). Mixing should continue until the plaster is uniformly distributed (approximately 2 to 4 minutes). The mixture must then be 
transferred rapidly to the test fixture mold. This should be done within 5-10 minutes of the completion of mixing. If necessary, it is allowable to prepare large quantities of this test material in several smaller batches. At least 16 hours should be allowed for this test material to cure and care should be taken to prevent water evaporation during curing.

Properties:

The K-Mag simulants reach much higher strengths than the salt/plaster simulants.

Composition \#1 will reach a compressive strength of approximately $21 \mathrm{MPa}$ (3000 psi) after 14 days (as determined by ASTM Standard Method D 1633-84: "Compressive Strength of Molded Soil Cement Cylinders"). Compositions 2 and 3 will reach about $10 \mathrm{MPa}$ (1500 psi) after 14 days of curing. Compositions 4 and 5 will reach only about $55 \mathrm{kPa}(8 \mathrm{psi})$ and $10 \mathrm{kPa}(1.5 \mathrm{psi})$, respectively, and will cure fully in about 16 hours at $20^{\circ} \mathrm{C}$. The densities of these simulants are 2.25 , $1.94,2.27,1.20$, and $1.20 \mathrm{~g} / \mathrm{cm}^{3}$ for compositions 1 through 5 , respectively. The uncertainty on all these density measurements is $\pm 0.05 \mathrm{~g} / \mathrm{cm}^{3}$. 


\subsection{Test Material Selection and Defensibility}

This section provides a brief discussion of the properties of the recommended test materials and the technical defensibility of each recommended simulant. As was stated earlier, it is not presently required that the specified test materials mimic the Hanford tank waste in every relevant respect. The purpose of the ACTR testing is to evaluate and compare competing retrieval methods rather than to make accurate predictions of retrieval-system performance on actual waste. Through testing, waste characterization, and further simulant development, it is expected that improved simulants will be developed that will allow defensible estimates of system performance on actual waste to be made. The present ACTR testing is one of the steps required to approach this goal.

\subsection{Wet Sludge}

The waste properties that are expected to have the greatest influence on the retrieval of wet sludge are discussed in this section. The defensibility of the recommended wet-sludge simulant is addressed through the comparison of selected actual waste and wet-sludge simulant properties.

\subsubsection{Relevant Properties for Wet Sludge}

The wet sludge properties postulated to be relevant for determining the performance of various candidate waste-retrieval technologies are identified in this section. The selection of these properties is based on a combination of testing results and literature reviews. Additional or alternate relevant properties may be selected, based on future testing results.

The key sludge properties for determining the performance of waterjet-based sludge-retrieval methods are thought to be sludge shear strength, sensitivity, cohesiveness, density, and waterabsorption rate. Sludge shear strength provides a measure of the capability of the sludge to resist the impinging waterjet. Sludge sensitivity is an indication of the effect of mechanical disruption on the sludge strength. A sludge with a high sensitivity will undergo a drastic decrease in shear strength upon disruption. Cohesiveness ${ }^{(a)}$ measures the tendency of the wet sludge to adhere to both itself and to pieces of process equipment. The rate of water absorption affects the rate that the large pieces of dislodged waste disintegrate and form a pumpable slurry. If the sludge contains an appreciable fraction of soluble solids, the solubility and dissolution rate of these solids may be important. In general, it is expected that partially soluble sludge will be retrieved at a greater rate than insoluble sludge, all other properties being equal. Sludge density is important because it influences the rate at which the pieces of dislodged sludge settle either within the tank or within the conveyance line.

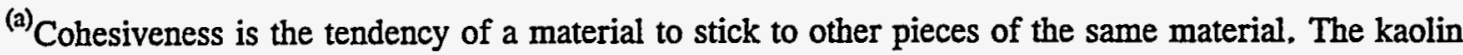
simulant, for example, is cohesive because separate pieces of kaolin readily stick together. Adhesiveness is the tendency of a material to stick to a different material. In order for a sludge waste to stick to process equipment it must be both adhesive and cohesive. If the waste is only adhesive, then only a thin film would form on the process equipment. If the waste is only cohesive, then not even a film will form. The nature of both the waste and the kaolin simulant make them tend to be both adhesive and cohesive. This is due to the fact that the adhesion/cohesion of these materials is due to the presence of colloidally-sized particles, which exhibit small, but significant, van der Waals attractions on both neighboring particles and neighboring surfaces.
} 
Tests using a variety of simulants indicate that the sludge-mobilization performance of submerged jet-based retrieval methods (e.g., mixer pumps) is determined primarily by the sludge cohesiveness (Powell et al. 1995). For many sludge-like materials, the maximum expected sludge cohesiveness is a function of the shear strength. The submerged-jet tests also show the importance of partial sludge solubility, but no significant dependence on sludge sensitivity has been found. Sludge sensitivity is expected to be more important for the non-submerged waterjet-retrieval methods. ${ }^{(a)}$ Tests using low pressure ( $<100 \mathrm{psi}$ ) water-in-air jets also imply a strong correlation between shear strength and the jet pressure of incipient mobilization (for example, see Figure 3.5).

Whether the list of postulated key sludge properties given above also applies to non-waterjetbased retrieval techniques is not certain. The exact nature of the candidate retrieval technique must be specified before such a determination can be made. It seems reasonable, however, that for techniques using mechanical cutting/dislodging blades, the sludge shear strength and cohesiveness would be quite important. Dissolution effects are probably of reduced or negligible importance, depending on the type of conveyance system employed.

With respect to wet sludge-retrieval conveyance system design, the greatest concern is that of conveyance line plugging. Shear strength, cohesiveness, and water-absorption rate are all relevant for conveyance systems. The justification for these key properties is described in Golcar et al. (1996).

\subsubsection{Simulant and Waste Property Comparison}

The test material designed to represent wet sludge is a mixture of kaolin clay and water. This test material has been extensively characterized by previous test programs. There are several properties of kaolin that make it a reasonable simulant for wet sludge. Comparisons of waste properties with those of $66 \%$ wt kaolin are given below.

The particle size distribution of EPK Pulverized kaolin clay has been measured using the same instrument as is used for waste samples and the results are similar (see Figures 3.1 and $3.2^{(b)}$ ). Effects of particle morphology are not addressed by such a comparison, but the plate-like shape of the kaolin particles is expected to render the kaolin conservatively cohesive (i.e., more sticky and difficult to retrieve than the waste).

(a) In mixer-pump based retrieval systems (submerged waterjet), the dislodged pieces of sludge are broken down into a slurry through the combined action of the mixer pump jet turbulence and travel of the dislodged pieces through the mixer pump volute. The shear stresses imposed on the sludge pieces within the mixer pump are likely much higher than either the disturbed or undisturbed sludge strength. Thus, it is not expected that the decrease in strength of a disrupted sensitive sludge will be of any consequence. In the non-submerged jet applications being considered (e.g., sluicing), the break-up of the dislodged sludge into slurry is performed by the impacting sluice jet turbulence. In this case, the stresses imparted to the dislodged sludge pieces are likely to be much lower. The decrease in sludge strength upon disruption may then accelerate the rate of slurry formation.

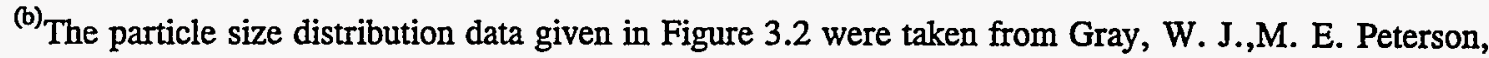
R. D. Scheele, and J. M. Tingey. 1990. Characterization of the Second Core Sample of NCAW from DST 101$A Z$. Letter Report prepared for Westinghouse Hanford Company by Battelle, Pacific Northwest Laboratories, Richland, Washington 99352. 


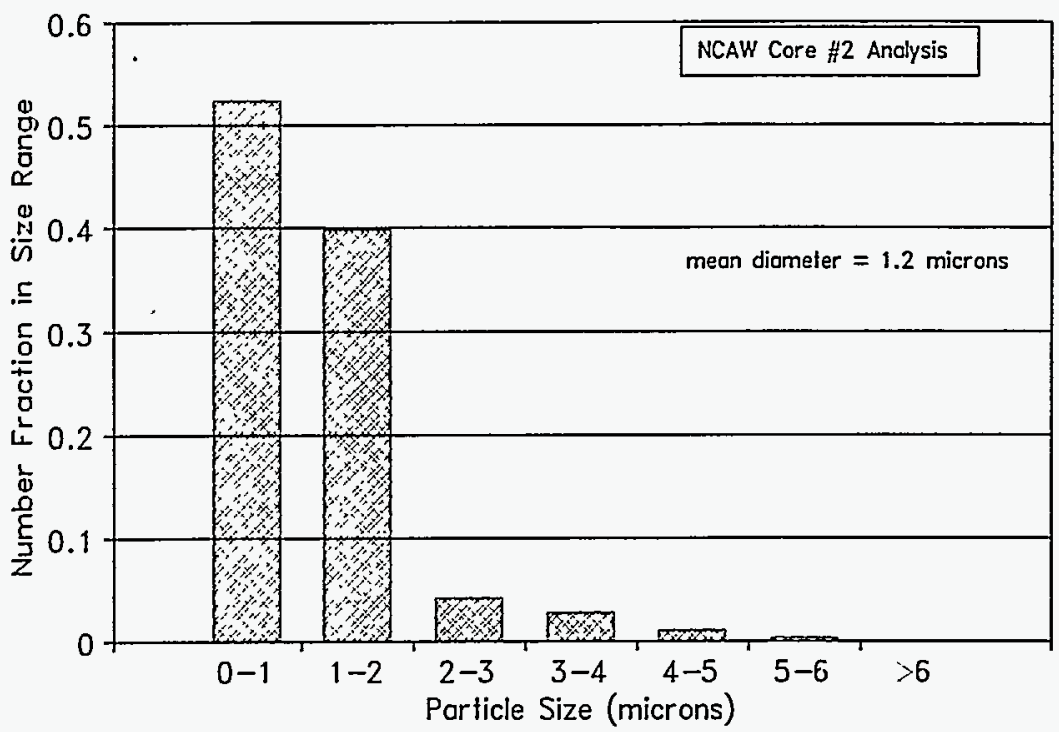

Figure 3.1. Particle Size Distribution: NCAW Core Sample \#2

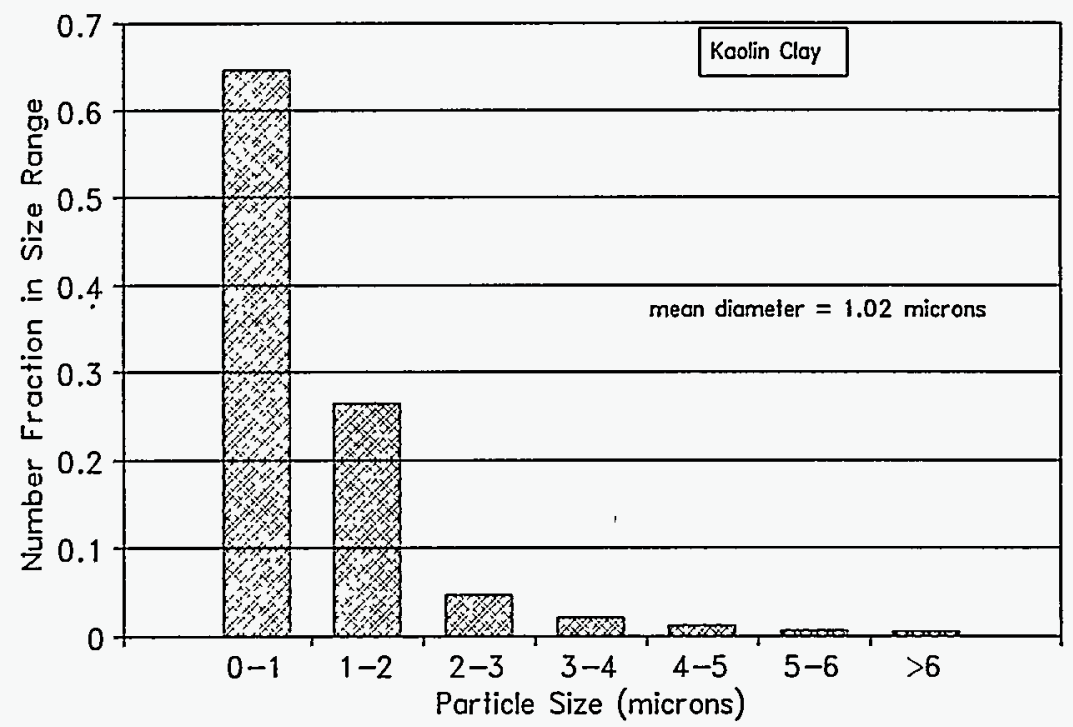

Figure 3.2. Particle Size Distribution: Kaolin Clay (Brinkmann Sample 93-01413) 
The kaolin clay shear strength and cohesiveness are thought to be reasonably similar to that of wet tank sludge, based on hot-cell measurements of shear strength and particle size as well as qualitative descriptions of waste behavior (e.g., "The solids were sticky..."(a) $)$. Tank sludge is observed to rinse off of hot-cell spatulas and glassware more readily than the kaolin simulant. This is further evidence that the kaolin simulant is conservatively adhesive.

At the specified solids concentration ( $66 \% \mathrm{wt}$ ), the kaolin simulant shear strength is about 3.5 $\mathrm{kPa}$. The shear strength of sludge samples from various Hanford waste tanks ranges from zero to near $5.0 \mathrm{kPa}$ (Willingham 1994). This is shown in Figure 3.3. Stronger sludge is expected in tanks where the waste has dried and/or reached high temperatures, but this waste type is addressed by the hardpan/dried-sludge simulants in Section 3.2.

The sensitivity of the waste to disruption is known to be significant. That is, mechanical disruption is known to decrease the shear strength of wet sludge. The amount of this decrease in strength varies depending on the waste type. The kaolin clay simulant has a relatively low sensitivity to disruption. This difference between waste and simulant may make the simulant more difficult to retrieve than the waste in some circumstances.

The rate at which waste imbibes fresh water is not known. Tests have shown that the kaolin clay simulant imbibes water very slowly (Powell et al. 1995). Thus, kaolin may be conservative with respect to water-absorption rate.

The range of wet sludge densities reported by Willingham (1994) is compared with the density of $66 \%$ wt kaolin clay in Figure 3.4. The kaolin mixture density is seen to fall within the range of measured sludge densities.

There are many factors that complicate simple comparisons of waste property data to simulant property data. For example, the disruption effects of core sampling may decrease the shear strength measured in the hot cell considerably, depending on the properties of the waste. Similarly, the fact that the particle size distributions, as given by the Brinkmann Model 2010 Particle Size Analyzer, are similar does not necessarily mean that the distributions actually are similar. The Brinkmann is not sensitive to particles smaller than about 0.5 microns, so any differences in the concentrations of these small particles will not be detected by the Brinkmann. It should be clear that some refinement to the waste simulants may be required as more waste characterization data become available.

\subsection{Hardpan/Dried Sludge}

Many Hanford tanks are known to contain a layer of sludge-like material that has solidified. Layers of hard sludge were encountered during past tank-sluicing campaigns. The sluice jets were found to be largely ineffective at removing this layer of "hardpan" waste. In some cases, the hardpan layer could be sluiced if fresh water was used as the sluice stream. It was hypothesized that some of

(a) Tingey, J. M., R. D. Scheele, M. E. Peterson, and M. R. Elmore. 1990. Characterization of Waste from Double-Shell Tank 103-AW. Letter Report prepared for Westinghouse Hanford Company by Battelle, Pacific Northwest Laboratories, Richland, Washington 99352. 


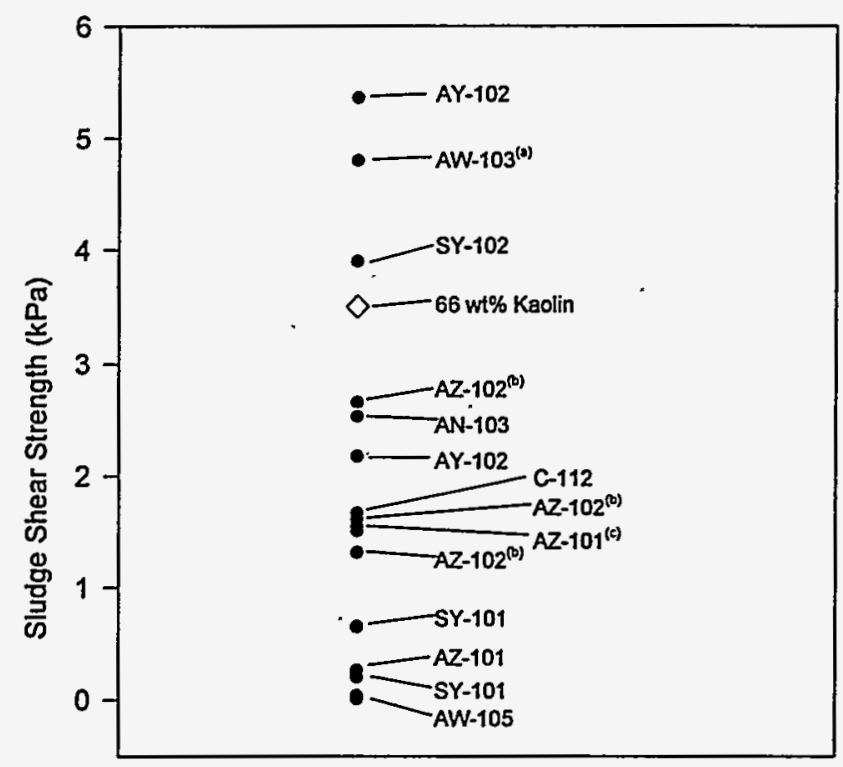

Figure 3.3. Plot Showing Range of Wet Sludge Shear Strengths.

The data used to generate this plot were taken from Willingham (1994) except as noted by superscripts $a, b$, and $c$. The data for the superscripted tanks are from:

(a) Tingey, J. M., R. D. Scheele, M. E. Peterson, and M. R. Elmore. 1990.

Characterization of Waste from Double-Shell Tank 103-AW. Letter Report prepared for Westinghouse Hanford Company by Battelle Pacific Northwest Laboratory, Richland, Washington 99352.

(b) Gray, W. J., M. E. Peterson, R. D. Scheele, and J. M. Tingey. 1991. Characterization of the First Core Sample of NCAW from DST 102-AZ. Letter Report prepared for Westinghouse Hanford Company by Battelle Pacific Northwest Laboratory, Richland, Washington 99352.

(c) Gray, W. J., M. E. Peterson, R. D. Scheele, and J. M. Tingey. 1990. Characterization of the Second Core Sample of NCAW from DST 101-AZ. Letter Report prepared for Westinghouse Hanford Company by Battelle Pacific Northwest Laboratory, Richland, Washington 99352. 


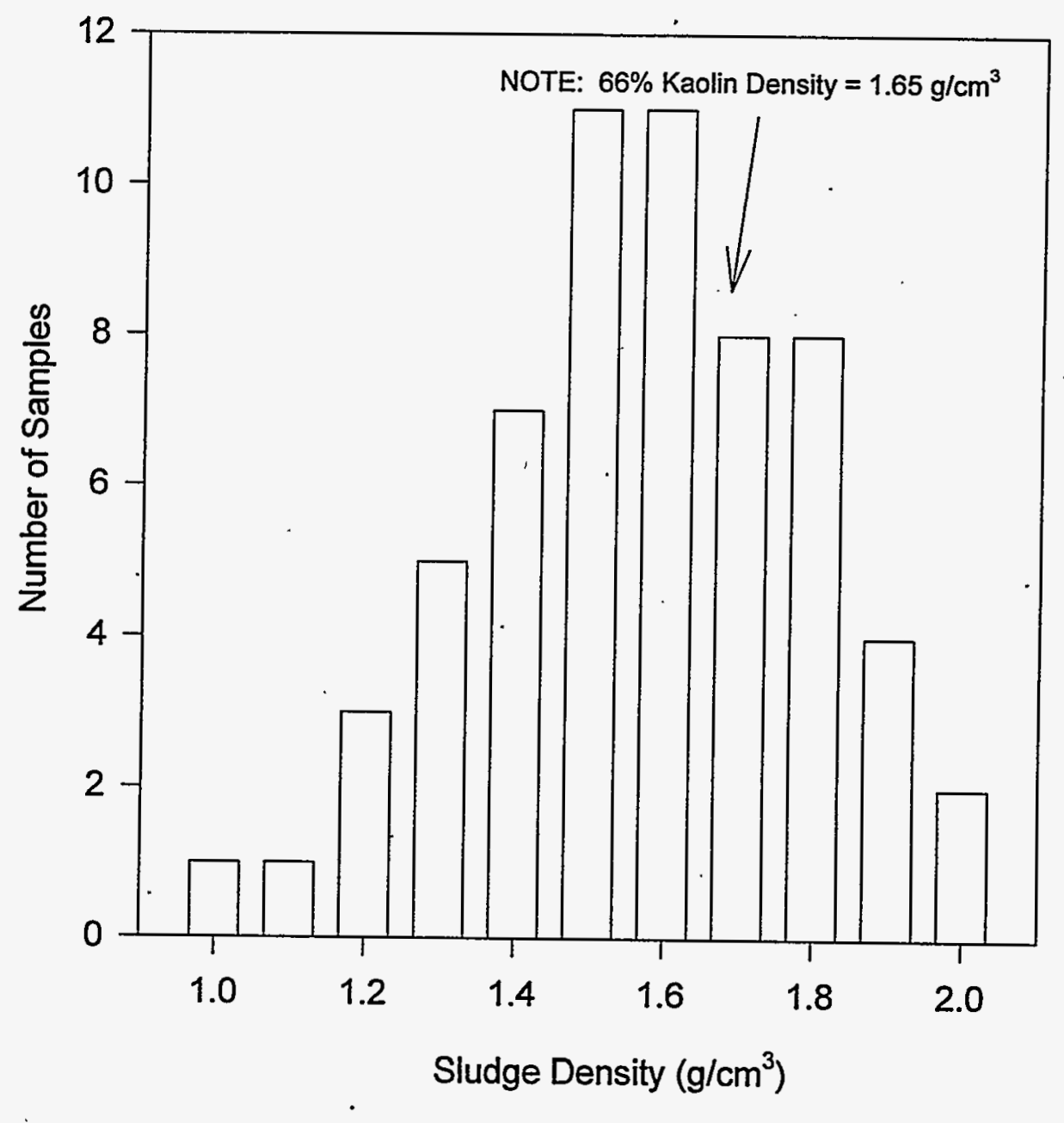

Figure 3.4. Histogram of Sludge Sample Densities. Data taken from Willingham (1994). 
the hardpan layers were composed of insoluble sludge particles and crystals of sodium uranyl carbonate (Rodenhizer 1987). In other tanks, the sludge has been allowed to dry and, in some cases, reach temperatures in excess of $100^{\circ} \mathrm{C}$. Bonding reactions between adjacent sludge particles are accelerated at higher temperatures and when the sludge is dried. It is postulated that these reactions have resulted in the formation of very hard sludge in some tanks. No samples of high-strength sludge have yet been obtained, so the extent to which these reactions may have affected the waste can only be speculated.

\subsubsection{Relevant Properties for Hardpan/Dried Sludge}

Retrieval technologies are needed to recover the hardpan sludge wastes. Test materials were developed to allow the evaluation of candidate retrieval technologies against simulated hardpan wastes. The recipes for these test materials were given in Section 2.0. The hardpan/dried sludge properties that control the performance of retrieval processes are not yet known.

It is hypothesized that waterjet-based and mechanical-cutting-based retrieval approaches for hardpan and dried sludge are most strongly dependent on the mechanical strength of the undisturbed waste. Shear-strength sensitivity to disruption and waste density are also judged to be important, as both affect settling and the rate of slurry formation. Salt dissolution may also be important, but this effect was not included in the present simulants. The extent to which the hardpan wastes are soluble is not known. Because it is possible that at least some of the hardpan wastes are wholly insoluble, it was judged prudent to formulate a non-dissolving hardpan simulant. Retrieval rates obtained from testing these simulants may be lower than those that would be obtained from a partially soluble hardpan simulant. Testing of these materials is needed to establish whether or not all the relevant properties are addressed by the simulants.

Some scoping tests were conducted in which a 4.8-mm (3/16-inch) diameter, vertically impinging water-in-air jet was directed normally to the surface of kaolin/plaster hardpan simulants of various strengths. The jet flow required to initiate visibly apparent erosion was determined. The data gathered are shown in Figure 3.5. It is seen that the jet flow required to begin the erosion of these simulants is strongly dependent on the simulant shear strength. The data shown indicate that the required jet pressure may be approximately equal to the simulant shear strength (the data fall roughly along the $y=x$ line). More such testing is required to establish the true mathematical relationship between simulant shear strength and incipient erosion produced by a sluice jet.

\subsubsection{Simulant and Waste Property Comparison}

The development of defensible hardpan/dried-sludge simulants is hindered by the complete lack of physical property data from hardpan waste samples. Some defensibility, however, can be obtained if the waste simulants are designed to develop strength through the same (or similar) mechanisms that operate in the tank waste. For the purpose of the present simulant-development efforts, the mechanisms operating in the hardpan and dried sludge waste types are taken to be the binding together of insoluble sludge particles by interstitial salt crystals (hardpan) and chemical bonding of sludge particles at their contact points. 


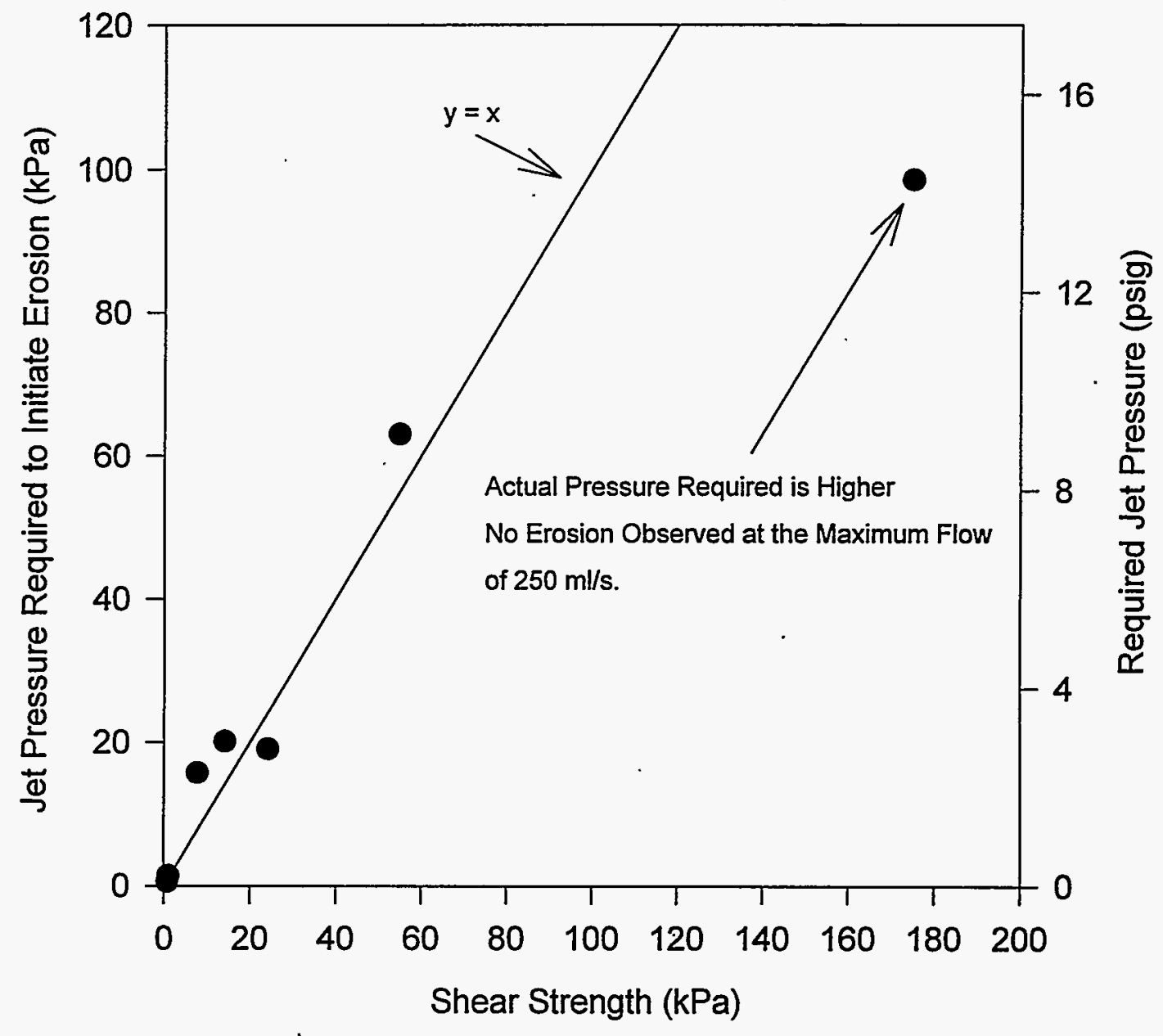

Figure 3.5. Eroding Sluice Jet Pressure vs. Shear Strength for Kaolin/Plaster Simulants 
The kaolin/plaster simulants specified in this report obtain mechanical strength via the formation of interlocking hydrated calcium sulfate crystals in the voids between kaolin clay particles. The strength of the cured simulant is controlled by adjusting the plaster concentration in the initial mix. The kaolin particles do not add significantly to the simulant strength, but instead serve to dilute the plaster (thereby limiting its strength) and to absorb the water that remains following the completion of the hydration reaction.

Because the strengths of the kaolin/plaster simulants are determined by the interlocking salt crystals, mixing this simulant (after it is cured) will greatly reduce its apparent strength. Mixing breaks down the calcium sulfate dihydrate crystals into small, non-interlocking pieces. The simulant strength remaining after extended mixing will be determined largely by the amount of free water that remains in the simulant mixed with kaolin clay. The simulants specified here have a relatively high water content to facilitate simulant preparation. ${ }^{\text {(a) }}$ As a result, the hardpan simulant residual strength after disruption is quite low. The residual strength can be increased by increasing the fraction of kaolin (or, equivalently, decreasing the fraction of water) in the simulant recipe.

The tendency of a fluid or paste to experience a decrease in its apparent viscosity with continued mixing is called thixotropy. This type of rheological behavior is common in slurries that obtain their shear resistance via the formation of gel structures or the interlocking of particles and crystals. Sludge-like materials that develop mechanical strength using these mechanisms are expected to be thixotropic. Materials that develop strength exclusively via interparticle attractive forces and interparticle friction are expected to not exhibit significant thixotropy.

The hardpan/dried sludge in the Hanford waste tanks is expected to develop its mechanical strength via a combination of interparticle attractions, friction, interlocking salt crystals, and chemical reactions at particle contact points. Mechanical disruption of this waste, then, should result in a decrease in its strength. The tank hardpan/dried sludge should exhibit some degree of thixotropy. The extent to which the strength is reduced by the disruption will depend on the fraction of the strength that is due to disruptable forces (e.g., interlocking salt crystals and interparticle reactions). Since these relative fractions are not yet known, the amount of thixotropy expected from tank waste is unknown. Adjustments to the relative fractions of kaolin and water, which control the residual strength, may be required as hardpan characterization data become available.

The kaolin clay appears to have the unintended effect of causing the simulant strength to reach a peak and then decrease to a stable value. A plot of simulant $\# 2$ ( $40 \%$ plaster) shear strength vs. time is shown in Figure 3.6. It is hypothesized that this behavior is due to a cation exchange reaction between the plaster (calcium sulfate) and the naturally occurring sodium ions in the clay. While interesting, this tendency is not expected to be relevant to the simulant defensibility.

(a) The specified hardpan/dried sludge simulant recipes contain enough water to allow the preparation of these simulants with commonly available mixing equipment. Decreasing the fraction of water in the simulant increases both the cured shear strength and the uncured apparent viscosity. The water fraction can be reduced to increase the residual strength (reduce the extent of thixotropy), but a specialized paste mixer may then be required to. prepare the simulants. 


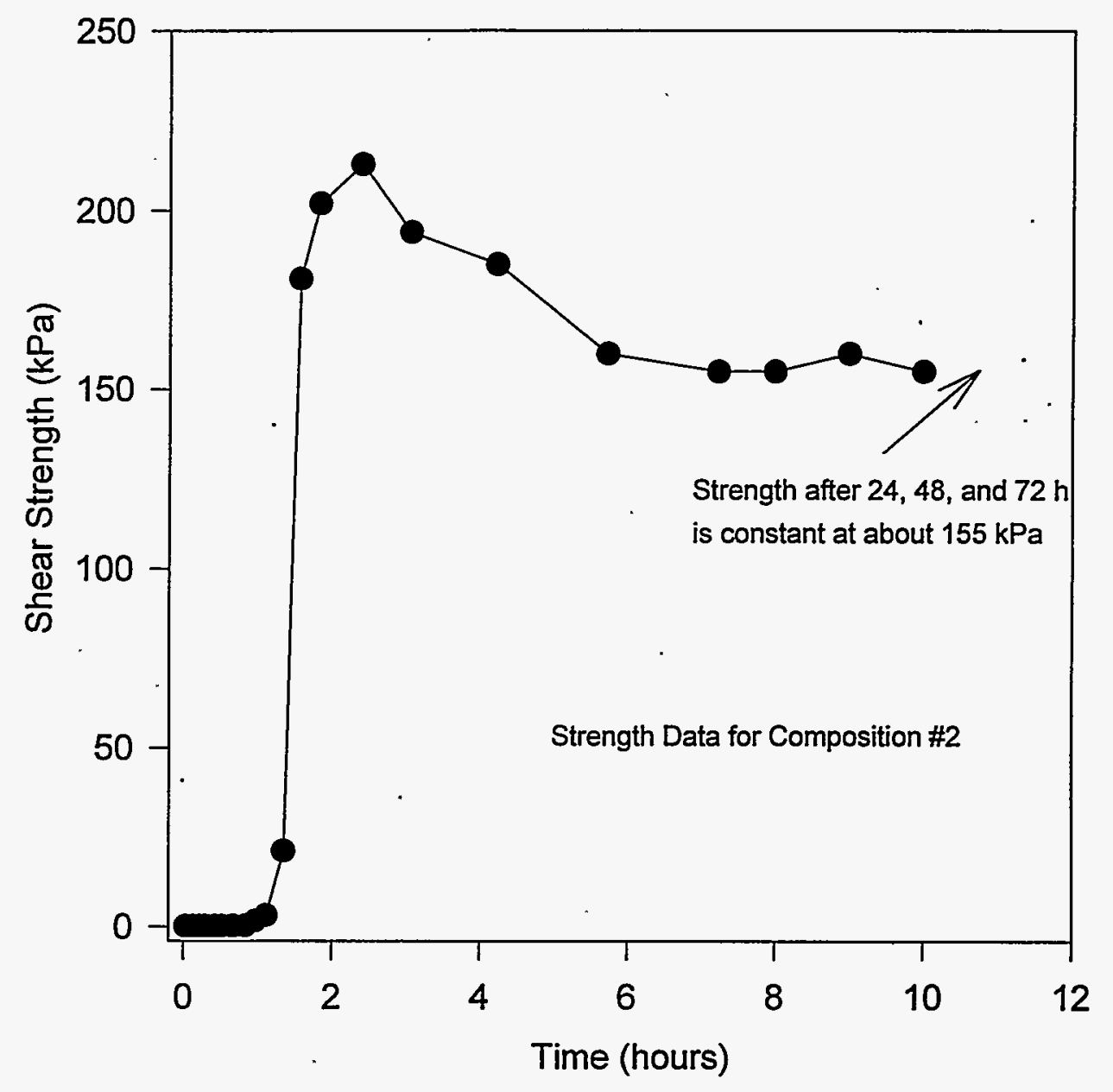

Figure 3.6. Shear Strength vs. Time for Hardpan Simulant \#2 
There are only two sources of semi-quantitative hardpan physical property data available. First, it has been noted that the Hanford past-practice sluicing jets were not capable of mobilizing the hardpan wastes at a significant rate. Second, samples of the hardpan layer have been described as having the "consistency of blackboard chalk" (Rodenhizer 1987).

Some Hanford past-practice sluicing campaigns were conducted using a flow rate of 300 to $350 \mathrm{gpm}$ out of a 1-inch nozzle (Rodenhizer 1987). The nozzle pressure required to obtain this flow with water is approximately $140 \mathrm{psig}$. It was found that the hardpan wastes in some tanks were capable of resisting the mobilizing force of these sluice jets. Accurate correlations between sludge strength and the jet pressure required to induce mobilization have not yet been developed. However, tests have revealed a linear relationship between the penetration resistance and the shear strength of various sludge-like materials. The pressure required to drive a cylindrical punch into several different sludge simulants was found to be approximately ten times the simulant shear strength. ${ }^{(a)}$

If the jet impact pressure exceeds the penetration resistance of the sludge, it is expected that mobilization will take place. Mobilization probably take place at lower pressures as well, but it is not yet known how much lower these pressures may be. The sluice jets lose some of their impact force as the jet breaks up in the air before impacting the sludge. At a typical sluicing distance of 30 feet, for example, the remaining maximum jet impact pressure is approximately $22 \%$ of the nozzle pressure. $^{(b)}$ Since the 140 psig sluice jets were not capable of mobilizing the hardpan wastes, it seems reasonable that the minimum penetration resistance of the hardpan is probably around $(0.22)(140 \mathrm{psi})$ $=31 \mathrm{psi}(214 \mathrm{kPa})$. Assuming the relationship between penetration resistance and shear strength holds for the hardpan waste, the shear strength of the hardpan is estimated to be $(1 / 10)(31 \mathrm{psi})=$ $3.1 \mathrm{psi}=21 \mathrm{kPa}$. This estimate for the hardpan shear strength is based on the assumption that the jet pressure required to initiate mobilization is 10 times the hardpan shear strength. As indicated in Figure 3.5, the required jet pressure may be considerably less than 10 times the shear strength. Regardless, the estimated hardpan shear strength compares reasonably well with the shear strengths of the two recommended hardpan/dried sludge simulants $(32 \mathrm{kPa}$ and $150 \mathrm{kPa})$. If the required jet pressure is 10 times the shear strength, then the estimated hardpan strength is $21 \mathrm{kPa}$ or greater. If the required jet pressure is about equal to the shear strength (as implied by Figure 3.5), then the estimated hardpan shear strength is $210 \mathrm{kPa}$ or greater.

As mentioned above, the hardpan waste has been described as having the "consistency of blackboard chalk." The shear strengths of two different brands of blackboard chalk were measured, using a direct-shear testing device. This device is pictured in Figure 3.7. Each 3/8-inch diameter piece of chalk was positioned within the shear tester, then weight was added slowly to the lower half of the tester until the chalk sample failed in shear. The average chalk shear strength was found to be $1720 \mathrm{kPa}(250 \mathrm{psi})$. This is considerably greater than the $150 \mathrm{kPa}(22 \mathrm{psi})$ shear strength of the stronger hardpan/dried sludge simulant. Whether the actual hardpan wastes are as strong (or stronger)

${ }^{(a)}$ This correlation is discussed in Powell, M. R., C. L. Fow, G. A. Whyatt, P. A Scott, and C. M. Ruecker. 1990. Proposed Test Strategy for the Evaluation of Double-Shell Tank Sludge Mobilization. Letter Report prepared for the U.S. Department of Energy by Battelle, Pacific Northwest Laboratories, Richland, Washington 99352.

${ }^{\text {(b) }}$ This is estimated using the empirical relationship between jet impact pressure and standoff distance given by Summers (1995). 
$\tau I^{\cdot} \varepsilon$

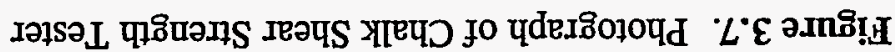

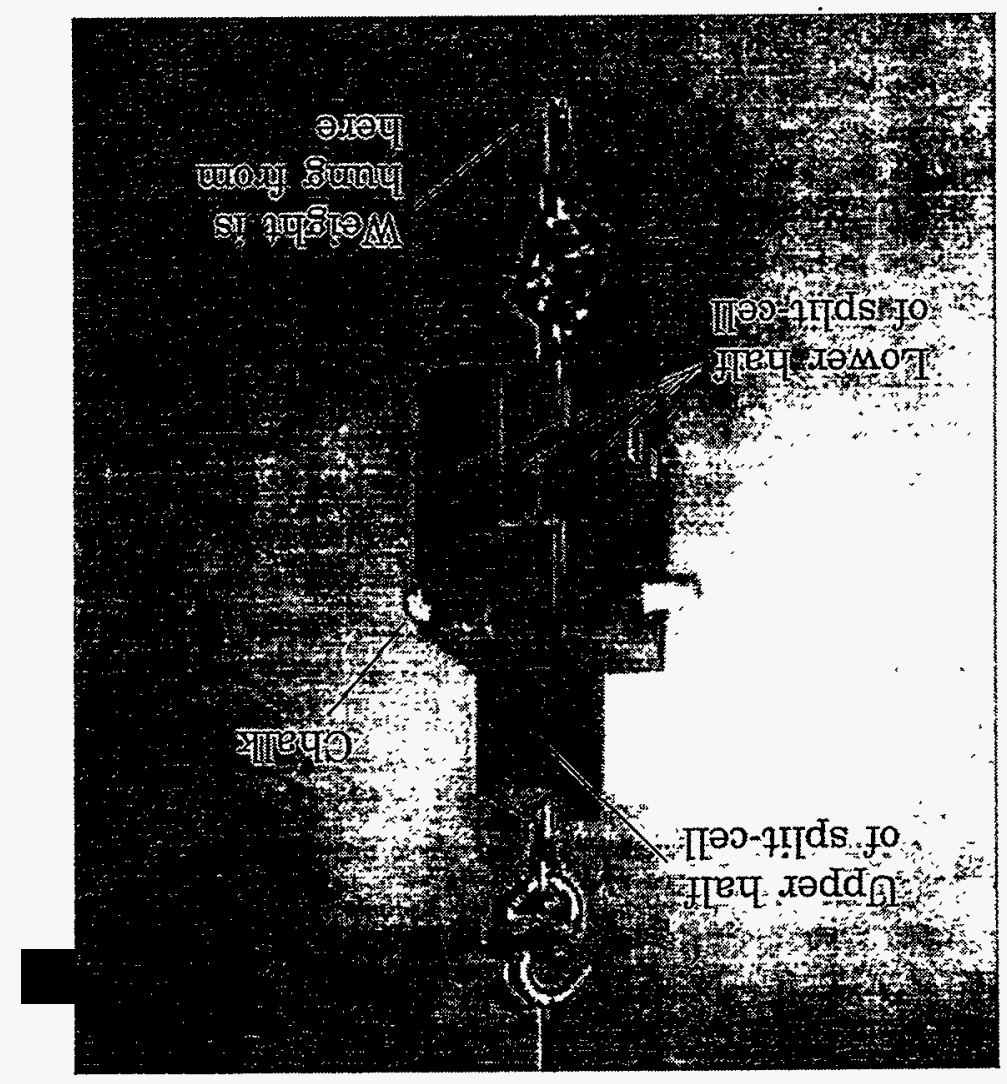


as the chalk samples is not known. It seems likely that the recommended hardpan simulants fall within the range of expected hardpan/dried sludge shear strengths, and it is possible that the hardpan simulants are weaker than the average hardpan waste. Whether this is the case cannot be determined until more hardpan characterization data are available.

\subsection{Saltcake}

The saltcake present in the Hanford tanks consists largely of sodium salts of nitrate, aluminate, nitrite, carbonate, phosphate, hydroxide, and sulfate. The exact compositions vary according to which process generated the waste and according to the subsequent history of waste in each tank. These differences are expected to give rise to a wide variety of physical and chemical properties. The mechanical strength of the saltcake, for example, is expected to vary over a range of perhaps 2 or more orders of magnitude, depending on the saltcake composition and history. ${ }^{\text {(a) }}$ Several different techniques have been proposed for saltcake retrieval at Hanford. These processes and the saltcake properties that determine the performance of these processes are described in this section. The similarities and differences between the proposed test materials to the Hanford saltcake wastes are also discussed.

\subsubsection{Relevant Properties for Saltcake Retrieval}

There are several saltcake properties known to influence the performance of saltcake-retrieval systems. Which properties that are most important, of course, depends on the type of retrieval process being considered. The performance of mechanical chopping techniques, for example, will be strongly dependent on the shear, compressive, and tensile strengths of the saltcake, but insensitive to the rate of saltcake dissolution. Waterjet-based techniques, however, are affected by saltcake dissolution rates as well as by selected mechanical strength and saltcake structure properties. The saltcake properties expected to have the greatest influence on several different saltcake-retrieval techniques are discussed below.

A considerable effort has been made at Hanford to develop high-pressure, waterjet-based saltcake-retrieval techniques. Small diameter jets of high-pressure water (between 10,000 and 60,000 psi) are used to cut the hard saltcake materials into small chunks roughly $1 \mathrm{~cm}$ in size. The cuttings are gathered as they are produced by a vacuum-based air conveyance or jet-pump driven pumping system. The conveyance system gathers both the cuttings and the water from the waterjets so that significant amounts of water are not added to the waste. This is desired to minimize the chance that tank waste could leak from the tanks during retrieval.

The rate at which the high-pressure waterjets cut hard saltcake is thought to be a function primarily of the salt crystal grain size, bulk porosity, pore connectedness, and tensile strength. Other

(a) Some chemically simulated saltcake has been found to have compressive strengths as high as $28 \mathrm{MPa}$ (4000 psi) (Wanner 1993). Samples of hard saltcake have not been taken from the tanks and analyzed to verify this estimated strength. Samples of soft saltcake, however, have been described as having the a "snow-cone" consistency, which would imply a very low compressive strength (i.e., $<10$ psi). 
factors that may be important include salt solubility, ${ }^{(a)}$ dissolution rate, and fracture toughness. This list of physical and chemical properties was developed through consultation with waterjet cutting experts and a consideration of the physics of waterjet cutting. A detailed discussion of the reasons for selecting each of these properties is given in Golcar et al. (1996).

Lower-pressure, waterjet-based saltcake-retrieval methods are also receiving attention. It is currently planned that the waste in many of the Hanford single-shell tanks will be retrieved by sluicing. The baseline sluicer design uses a $2.5 \mathrm{~cm}$ (1 inch) diameter nozzle discharging liquid (either a dilute slurry or inhibited water) at an exit velocity of about $46 \mathrm{~m} / \mathrm{s}(150 \mathrm{ft} / \mathrm{s})$. This high volumetric flow, low pressure technique will rely primarily on dissolution to effect the retrieval of hard saltcake. Softer saltcake wastes may be dislodged by the impacting jet in addition to dissolving.

The saltcake sluicing retrieval rate is expected to be a function primarily of the dissolution rate of the saltcake. The dissolution rate will likely be increased if the sluice jet is powerful enough to overcome the mechanical strength of the soft saltcake, but this unlikely to occur for the hard saltcake. The dissolution rate of saltcake-like materials is a function of the saltcake composition, porosity, grain size, and grain shape, as well as the properties of the sluicing fluid (e.g., fluid composition, flow rate, and temperature [Helgeson et al. 1984; Aagaard and Helgeson 1982]).

\subsubsection{Simulant and Waste Property Comparison}

Very little characterization of Hanford saltcake physical properties has been completed. There are some chemical composition data that have been developed based on a combination of measurement and process flowsheet analyses (e.g., Kupfer 1981), but physical property data are qualitative at best. No measurements of saltcake tensile strength, compressive strength, porosity, or fracture toughness have been made. However, the need to support retrieval system testing with defensible saltcake simulants remains. At present, only qualitative comparisons between simulant and saltcake properties can be made for most of the key properties discussed in Section 3.3.1. The quantitative and qualitative comparisons that can be made are described below.

\section{Mechanical Strength Properties}

The physical properties of tank saltcake have not been measured, but it is suspected that there is wide variation in those properties (Krieg 1992). In-tank photographs and operational experiences indicate that some tanks contain relatively soft saltcake while others contain very hard saltcake. It has been suggested that the soft saltcake waste was formed when solids-laden evaporator effluent slurry was pumped into the tanks. The interstitial liquor was subsequently removed by pumping and

\footnotetext{
(a) Recent testing at the University of Oklahoma implies that the dissolution of the K-Mag saltcake simulants may be significant during high-pressure (1 to $5 \mathrm{kpsi}$ ) waterjet cutting (Performance Analysis of Water-Jet Cutting Technology on Saltcake Erosion as a Function of Temperature, Pressure, and Stand-off Distance. by Baeza, Scopel, and Gremillion of the University of Oklahoma. December 14, 1995). Increasing the temperature of the waterjet fluid was found to increase the rate of cutting. Whether this is due solely to enhanced K-Mag dissolution kinetics or to other, less obvious factors is not yet known. For example, the higher temperature waterjet fluid may have a reduced interfacial tension (between the saltcake and the water) or decreased viscosity, which will tend to improve performance by allowing the waterjet to penetrate into the saltcake pores more readily. It is not known whether water temperature effects are significant for $>5 \mathrm{kpsi}$ waterjets.
} 
evaporation, leaving a loosely-bound matrix of salt crystals. The hard saltcake supposedly formed via a slow, in-tank crystallization that resulted as water evaporated from the liquid tank waste.

Much of the previous saltcake simulant work has been focused on the development of simulants for the hard saltcake wastes (Golcar et al. 1996). The sulfur K-Mag simulants described in Section 2.0 (saltcake compositions 1 through 3) were developed for the testing of high-pressure waterjet-based retrieval methods. The retrieval systems being designed had to be robust enough to retrieve all waste types at the target waste retrieval rate successfully. Because the hard saltcake was judged to represent the greatest challenge to these high-pressure waterjet systems, an effort was made to develop a simulant for the hard saltcake. If the waterjet systems could be designed to handle the hard saltcake simulant, then it was expected that they would also be able to handle the other waste types (e.g., sludge, hardpan, soft saltcake).

To support the high-pressure waterjet system development, saltcake simulants similar to the hard saltcake waste were needed. No samples of hard saltcake were available for characterization, so the physical properties of some chemically-based simulants were measured (Wanner 1993). The compressive strengths of these chemical simulants were used to establish the target compressive strengths for the K-Mag saltcake simulants. The chemical simulants could not be used directly because of the hazards and associated disposal costs. The $84 \% \mathrm{~K}-\mathrm{Mag}$ simulant was developed to produce the target hard saltcake compressive strength of about $21 \mathrm{MPa}(3000 \mathrm{psi}){ }^{(\mathrm{a})}$

The $10 \mathrm{MPa}$ (1500 psi) K-Mag simulants (compositions 2 and 3) were developed to allow the testing of high-pressure waterjet-based retrieval methods on simulants with different mechanical strengths and porosities. The porosity of the composition 2 saltcake is much greater than that of the composition 3 saltcake (Golcar et al. 1996). Developing an understanding of the hard saltcake physical properties that control high-pressure waterjet effects is an ongoing effort in the Retrieval Process Development and Enhancements Project.

The simulants made from rock salt and plaster of paris (compositions 4 and 5) were developed to provide test materials expected to be similar to the soft saltcake. No quantitative sample characterization data are available on which to base the target mechanical strength of soft saltcake simulants. There are recent indications that some of the soft saltcake may be soft enough to allow the emplacement of in-tank probes with a minimal amount of force. What this means in terms of measurable strength properties (e.g., compressive strength) must be evaluated. However, there are qualitative descriptions indicating the soft saltcake is a very weak material ("slushy snow cone" consistency; Wong 1990). This qualitative description was used as the basis for selecting mechanical strength target values for the weak salt/plaster simulants. The specified simulants have very low compressive strengths, as shown in Figure 3.8. ${ }^{(b)}$ The strengths of the specified simulant recipes are

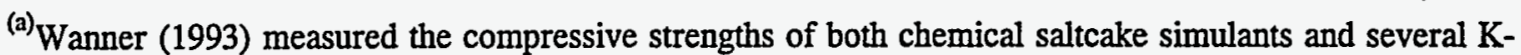
Mag simulant samples. The K-Mag strengths reported by Wanner are considerably lower than those found by more recent testing at PNNL. The discrepancy is due to differences in the K-Mag curing procedure. Wanner allowed the samples to dry while curing, which decreased the extent of langbeinite hydration. Much lower compressive strengths resulted.

(b) The 5\% plaster $195 \%$ rock sait simulant is weak enough that samples of this simulant must be handled carefully. Even light pressure can cause the sample to crumble.
} 
shown on the plot at $5 \%$ and $14 \%$ plaster. These strengths are low enough that it is likely a directly impinging sluice jet will effect mechanical disruption of the simulants.

\section{Saltcake Dissolution Rate}

It must be stressed that the K-Mag simulants were not originally developed to model the dissolution characteristics of hard saltcake. The dynamics of high-pressure waterjet cutting were thought to be fast enough that dissolution would be of secondary importance compared to properties like tensile strength, granularity, porosity, and fracture toughness. ${ }^{\text {(a) }}$ K-Mag simulants, however, do dissolve slowly and, therefore, may have some usefulness as simulants for high-volumetric flow sluicing-based retrieval methods that rely on waste dissolution. The dissolution rate of K-Mag, however, is considerably slower than that of the sodium nitrate and nitrite salts that comprise the bulk of the actual saltcake wastes.

Whether or not K-Mag simulants can be used to model actual hard saltcake dissolution is not yet known and requires further study. However, for retrieval methods that do not rely heavily on salt-dissolution effects (e.g., high-pressure waterjets or mechanical choppers/cutters), the K-Mag simulants are reasonable. Efforts are being made to identify materials that can be used to formulate representatively soluble simulants for hard saltcake. This effort is made more difficult by the requirement that the simulants not be too expensive to prepare and/or dispose.

It was judged important for the soft saltcake simulant to be highly-soluble and porous (like soft saltcake waste) so that dissolution-based retrieval methods (e.g., sluicing) could be evaluated using this test material. For this reason, rock salt (sodium chloride) was used rather than the more slowly-soluble sulfur K-Mag. The rock salt dissolution rate is apparently not affected appreciably by the presence of the plaster. As more plaster is added to the mix, a greater fraction of the salt-crystal surface area becomes coated with plaster, which would be expected to result in a decreased dissolution rate. Comparisons of the dissolution rates for the plaster/rock salt simulants and the untreated (no plaster) rock salt reveal that this effect is minor. The plaster coating is observed to flake away rapidly from the surface of the dissolving salt particles.

To demonstrate the differences in dissolution rates between saltcake constituents (e.g., sodium nitrate and nitrite) and the specified simulant materials, a series of dissolution tests were conducted. Each test involved placing $10.00 \pm 0.05 \mathrm{~g}$ of the salt being tested into $100.0 \pm 0.1 \mathrm{~g}$ of deionized water. A $9.1 \mathrm{wt} \%$ final solution concentration was arbitrarily selected for this study. A dissolutionbased retrieval method might employ higher or lower final concentrations. Each mixture was continuously agitated at the same rate, using a magnetic stir-bar. The time required to dissolve each sample completely was recorded. The data from these tests are given in Table 3.1 below.

The salt solubility data for all the salts given in Table 3.1, except $\mathrm{K}-\mathrm{Mag}$, were taken from Sohnel and Novotny (1985). The K-Mag solubility data were obtained from the material safety data sheet for potassium magnesium sulfate (K-Mag).

\footnotetext{
${ }^{\text {(a) }}$ The University of Oklahoma study mentioned earlier provides evidence that K-Mag dissolution may be . significant for high-pressure waterjet-based retrieval techniques.
} 


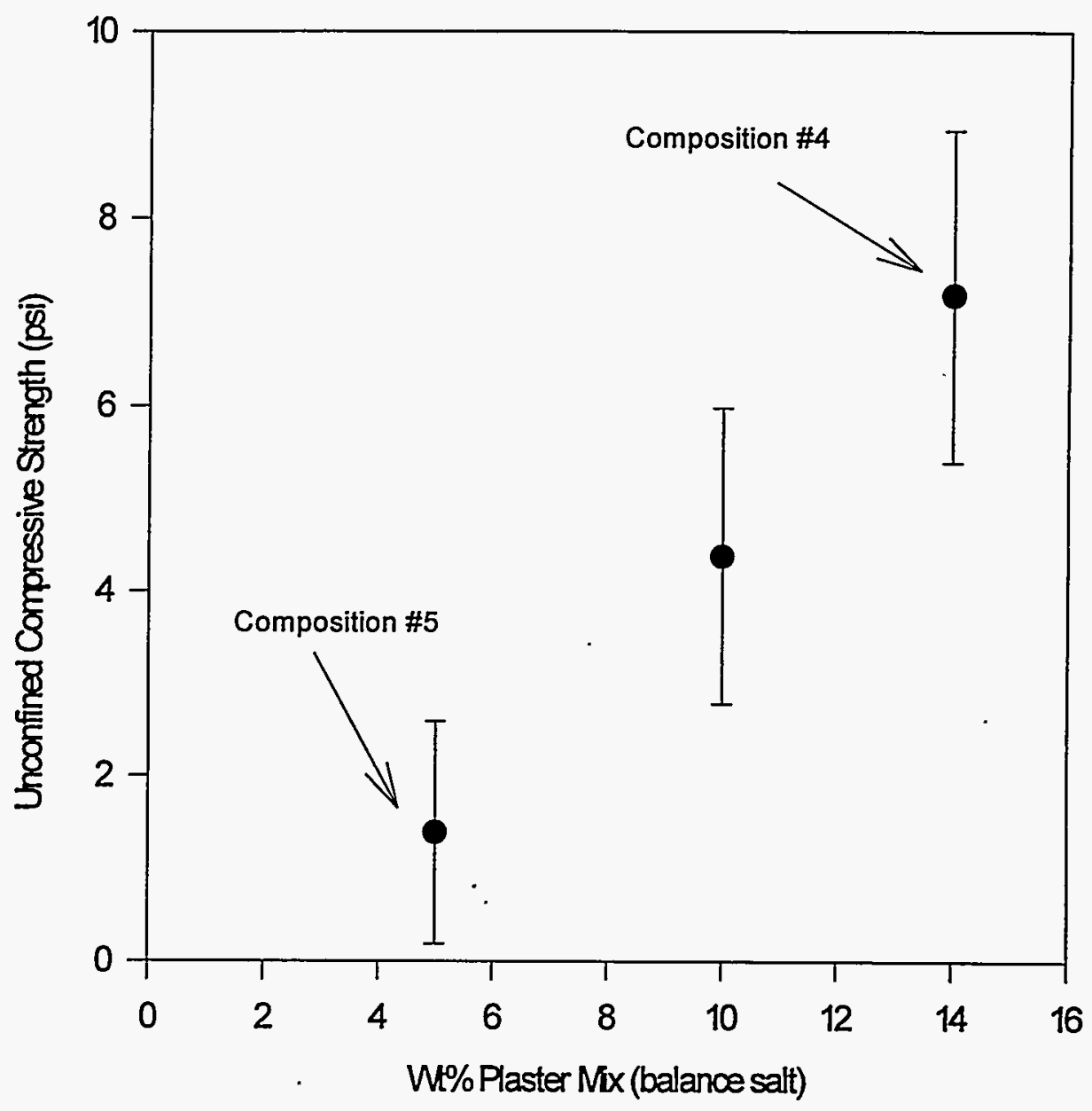

Figure 3.8. Compressive Strength of Salt/Plaster Simulants 
The dissolution rate data given in the table below are intended to provide an indication of the magnitudes of differences in dissolution rates between the various salts. Even small differences in particle sizes and shapes can lead to significant differences in the apparent dissolution rate. This fact is illustrated by the factor-of- 5 difference in dissolution times between the rock salt $(\mathrm{NaCl})$ and the 0.3-mm-sized granules of $\mathrm{NaCl}$. The dissolution rate of a salt is a function of the effective particle surface area for dissolution, the intensity of mixing, the liquid-phase composition, temperature, and the chemical activities of the ionic species (Helgeson et al. 1984).

Despite the differences in particle morphology, the test data given in the table allow several conclusions to be drawn. First, it is clear that sodium nitrate and nitrite salts dissolve more quickly in water than does sodium chloride (assuming equal particle sizes). The sodium nitrite was observed to dissolve completely in 39 seconds, while the similar-sized sodium chloride sample required 59 seconds. The sodium nitrate sample dissolved in 62 seconds despite having a much larger initial particle size than the small granules of sodium chloride.

The second conclusion that can be drawn is that the K-Mag saltcake simulant (composition 1) dissolves much more slowly than do the other salts tested. About 15 minutes were required to dissolve $90 \%$ of the composition 1 saltcake-simulant particles. After an hour of mixing some solids still remained. The K-Mag saltcake simulant consists of hydrated potassium magnesium sulfate. The hydration reaction is rather slow, as is indicated by the long cure time for this simulant (approximately 14 days). The dissolution data for unhydrated K-Mag shown in Table 3.1 provide further evidence of the slow hydration rate. The (initially) unhydrated K-Mag requires many hours to dissolve, instead of minutes like the hydrated K-Mag (saltcake simulant composition 1).

The third conclusion drawn from the dissolution data is that the plaster coating on the soft saltcake simulants (compositions 4 and 5) does not appreciably affect the dissolution rate. The rock salt sample (no plaster) was found to dissolve completely in 297 seconds. The rock salt/plaster simulants dissolved in about the same length of time $(290 \mathrm{sec}$. and $314 \mathrm{sec}$. for compositions 4 and.5, respectively).

The dissolution rate data imply that the rock salt/plaster saltcake simulant will dissolve more slowly than the sodium nitrate and nitrite salts that make up most of the saltcake waste. There are a couple of factors, however, that complicate a direct comparison of the rock salt and sodium nitrate/nitrite dissolution data. First, the saltcake waste particle sizes/shapes are not accurately known and, in some cases, the relevant saltcake-particle characteristics will be dependent on the type of retrieval system employed. Second, the dissolution rate of sodium nitrate and nitrite salts in water does not necessarily reflect the dissolution rate of these salts into the retrieval fluid. During sluicing operations, for example, the retrieval fluid will likely be at a high $\mathrm{pH}$ and contain other dissolved salts. The common-ion effect on solubility is expected to decrease the dissolution rate of saltcake, compared to what would be measured if clean water was used as the retrieval fluid. 
Table 3.1. Salt Dissolution Times in Water

\begin{tabular}{|c|c|c|c|c|}
\hline \multicolumn{5}{|c|}{$\begin{array}{l}\text { Dissolution Times for } 10 \mathrm{~g} \text { of Salt into } 100 \mathrm{~g} \text { of Water at } 21^{\circ} \mathrm{C} \\
\text { (agitation intensity held constant) }\end{array}$} \\
\hline Salt & Solubility (wt\%) & $\begin{array}{c}\text { Particle } \\
\text { Description } \\
\text { (initial size/shape) }\end{array}$ & $\begin{array}{l}\text { Estimated } \\
\text { Initial } \\
\text { Surface } \\
\text { Area }^{\dagger}\end{array}$ & $\begin{array}{l}\text { Dissolution } \\
\text { Time } \\
\text { (sec.) }\end{array}$ \\
\hline $\mathrm{NaCl}$ & 26 & $\begin{array}{l}\text { roughly cubic granules } \\
0.2-0.7 \mathrm{~mm} ; \text { Avg. } \approx 0.3 \mathrm{~mm}\end{array}$ & $9 \mathrm{~m}^{2} / \mathrm{kg}$ & 59 \\
\hline $\mathrm{NaNO}_{2}$ & 45 & $\begin{array}{l}\text { roughly cubic granules } \\
0.2-0.7 \mathrm{~mm} ; \text { Avg. } \approx 0.3 \mathrm{~mm}\end{array}$ & 9 & 39 \\
\hline $\mathrm{NaNO}_{3}$ & 47 & $\begin{array}{l}\text { spherical pellets } 2-3 \mathrm{~mm} \\
\text { diameter; Avg. } \approx 2.5 \mathrm{~mm}\end{array}$ & 1.1 & 62 \\
\hline $\begin{array}{l}\text { Rock Salt } \\
(\mathrm{NaCl})\end{array}$ & 26 & $\begin{array}{l}\text { irregular shaped particles } \\
2-10 \mathrm{~mm} \text {; Avg. } \approx 4 \mathrm{~mm}\end{array}$ & 0.7 & 297 \\
\hline $\begin{array}{l}\text { Saltcake } \\
\text { Simulant } \\
\text { Comp. \#4 }\end{array}$ & $27^{\ddagger}$ & $\begin{array}{l}\text { irregular shaped particles } \\
2-10 \mathrm{~mm} \text {; Avg. } \approx 4 \mathrm{~mm}\end{array}$ & 0.7 & 290 \\
\hline $\begin{array}{l}\text { Saltcake } \\
\text { Simulant } \\
\text { Comp. \#5 }\end{array}$ & $30^{\ddagger}$ & $\begin{array}{l}\text { irregular shaped particles } \\
2-10 \mathrm{~mm} \text {; Avg. } \approx 4 \mathrm{~mm}\end{array}$ & 0.7 & 314 \\
\hline $\begin{array}{l}\text { K-Mag } \\
\text { (not } \\
\text { hydrated) }\end{array}$ & 24 & $\begin{array}{l}\text { irregular shaped particles } \\
2-10 \mathrm{~mm} \text {; Avg. } \approx 4 \mathrm{~mm}\end{array}$ & 0.7 & $\begin{array}{l}\approx 90 \% \text { in } \\
13 \mathrm{hrs} .\end{array}$ \\
\hline $\begin{array}{l}\text { Saltcake } \\
\text { Simulant } \\
\text { Comp. \#1 } \\
\text { (K-Mag) }\end{array}$ & 29 & $\begin{array}{l}\text { irregular shaped particles } \\
2-10 \mathrm{~mm} ; \text { Avg. } \approx 4 \mathrm{~mm}\end{array}$ & 0.7 & $\begin{array}{l}\approx 75 \% \text { in } \\
5 \mathrm{~min} . \\
\approx 90 \% \text { in } \\
15 \mathrm{~min} .\end{array}$ \\
\hline
\end{tabular}

${ }^{\dagger}$ The initial specific surface area was estimated for each solid by assuming all particles were uniform in shape and of average size. Cubical shape was assumed for all salts, except for sodium nitrate for which spherical shape was assumed.

${ }^{\ddagger}$ The rock salt/plaster simulants will reach saturation with respect to sodium chloride at the indicated concentrations of simulant (which both correspond to a $26 \%$ concentration of sodium chloride in the solution). The plaster portion of each simulant will not appreciably dissolve. 
There are indications ${ }^{(a)}$ that the size of some saltcake crystal particles range from about 0.2 $\mathrm{mm}$ to $0.6 \mathrm{~mm}$. If this characterization is accurate, the saltcake dissolution rate into water is expected to be faster than that of the rock salt/plaster simulants. When salt-laden or high $\mathrm{pH}$ fluids are used to dissolve the waste, the saltcake dissolution rate is expected to be reduced by the common-ion effect on solubility. Whether the dissolution rate is significantly affected will depend on the dissolving fluid composition.

In an effort to investigate the magnitude of the common-ion effect on dissolution rate, another series of experiments were conducted. In each of these experiments, $10.00 \pm 0.05 \mathrm{~g}$ of salt (sodium nitrate or chemically based saltcake simulant) was mixed into $100.0 \pm 0.1 \mathrm{~g}$ of either water or sodium hydroxide solution. The time required to dissolve all of the visible salt particles was recorded in each case. The results are shown in Table 3.2 below.

It is seen in Table 3.2 that increasing $\mathrm{NaOH}$ concentration increases the sodium nitrate dissolution time. The dissolution time increases by approximately $50 \%$ as the $\mathrm{NaOH}$ concentration is increased from zero to 4 moles/liter. Based on these data, it seems likely that the soft saltcake dissolution rate in high $\mathrm{pH}$ fluids will be greater than that exhibited by the rock salt/plaster saltcake simulants. in water. The larger particle size and lower solubilization rate of the rock salt simulants (compared to sodium nitrate) result in a dissolution time in water roughly 3 times that of the sodium nitrate in 4 molar $\mathrm{NaOH}$. Thus, it is expected that dissolution-based retrieval of the rock salt/plaster simulants will yield somewhat slower retrieval rates than the actual soft saltcake. The magnitude of the difference will depend largely on the actual particle size and porosity of the soft saltcake and on the composition of the dissolving fluid. It seems likely, though, that the rock salt/plaster simulants can provide an order-of-magnitude (or better) estimate of the soft saltcake retrieval rate.

Also shown in Table 3.2 are dissolution time data for a chemical saltcake simulant. This simulant was prepared to support a previous testing program and was based on core sample and flowsheet analyses. ${ }^{(b)}$ The simulant is comprised of sodium and aluminum salts of nitrate, nitrite, hydroxide, carbonate, sulfate, and phosphate. It is worthwhile to note that the dissolution time of this simulant is about equal to that of the sodium nitrate even though this material has much smaller particles. The particle size of this simulant approximates that of soft saltcake waste. The lower dissolution rate of this simulant is attributed to the presence of the more slowly soluble carbonate, sulfate, and phosphate salts. This saltcake simulant is not practical for use in large-scale retrievalsystem testing because it is difficult and expensive to prepare and cannot easily be disposed.

(a) Janicek, G. P. 1981. Equipment Development Study for Hydraulic Recovery of Single-Shell Tank Sludges. RHO-CD-1533. Letter report prepared for the U.S. Department of Energy by Rockwell Hanford Operations Energy Systems Group. Richland, Washington 99352.

${ }^{(b)}$ Morrey, E. V., E. A. Aaron, M. D. Ryder, J. W. Virden, and G. W. Gee. 1994. Feasibility Study of Using Colloidal Silica to Temporarily Immobilize Tank Supernatant: Status Report (FY 1993). Report prepared for Westinghouse Hanford Company by Pacific Northwest Laboratory, Richland, Washington 99352. 
Table 3.2. Salt Dissolution Times vs. $\mathrm{NaOH}$ concentration

\begin{tabular}{|c|c|c|c|}
\hline \multicolumn{4}{|c|}{$\begin{array}{c}\text { Dissolution Times for } 10 \mathrm{~g} \text { of Salt into } 100 \mathrm{~g} \text { of Fluid at } 21^{\circ} \mathrm{C} \\
\text { (agitation intensity held constant) }\end{array}$} \\
\hline Salt & $\begin{array}{l}\text { Diluent Fluid } \\
\quad(100 \mathrm{~g})\end{array}$ & $\begin{array}{c}\text { Particle } \\
\text { Description } \\
\text { (initial size/shape) }\end{array}$ & $\begin{array}{l}\text { Dissolution } \\
\text { Time } \\
\text { (sec.) }\end{array}$ \\
\hline $\mathrm{NaNO}_{3}$ & Water & $\begin{array}{l}\text { spherical pellets } 2-3 \mathrm{~mm} \\
\text { diameter; Avg. } \approx 2.5 \mathrm{~mm}\end{array}$ & 62 \\
\hline $\mathrm{NaNO}_{3}$ & $1 \mathrm{M} \mathrm{NaOH}$ & $\begin{array}{l}\text { spherical pellets } 2-3 \mathrm{~mm} \\
\text { diameter; Avg. } \approx 2.5 \mathrm{~mm}\end{array}$ & 69 \\
\hline $\mathrm{NaNO}_{3}$ & $2 \mathrm{M} \mathrm{NaOH}$ & $\begin{array}{l}\text { spherical pellets } 2-3 \mathrm{~mm} \\
\text { diameter; Avg. } \approx 2.5 \mathrm{~mm}\end{array}$ & 78 \\
\hline $\mathrm{NaNO}_{3}$ & $4 \mathrm{M} \mathrm{NaOH}$ & $\begin{array}{l}\text { spherical pellets } 2-3 \mathrm{~mm} \\
\text { diameter; Avg. } \approx 2.5 \mathrm{~mm}\end{array}$ & 98 \\
\hline $\begin{array}{l}\text { Chemical } \\
\text { Saltcake } \\
\text { Simulant } \\
\end{array}$ & Water & $\begin{array}{l}\text { roughly cubic granules } \\
0.2-0.7 \mathrm{~mm} \text {; Avg. } \approx 0.3 \mathrm{~mm}\end{array}$ & 64 \\
\hline $\begin{array}{l}\text { Chemical } \\
\text { Saltcake } \\
\text { Simulant }\end{array}$ & $2 \mathrm{M} \mathrm{NaOH}$ & $\begin{array}{l}\text { roughly cubic granules } \\
0.2-0.7 \mathrm{~mm} \text {; Avg. } \approx 0.3 \mathrm{~mm}\end{array}$ & 76 \\
\hline
\end{tabular}

\section{Porosity}

The porosity of Hanford saltcake has not been measured, but estimates range between $10 \%$ and 50\% (Krieg 1992). Porosity measurements of the K-Mag saltcake simulants have been made using a mercury porosimeter. The K-Mag porosity is found to vary between about $10 \%$ and $20 \%$, depending on the water content in the initial mix. The porosity of the rock salt/plaster saltcake simulants (compositions 4 and 5) is estimated to be approximately $40 \%$ based on the known plaster, salt, and simulant densities. The K-Mag saltcake simulants are near the lower end of estimated saltcake porosities, and the rock salt/plaster simulants are near the upper end.

\subsection{Conclusions}

The waste properties that are expected to determine the performance of various candidate waste-retrieval systems have been identified. Some refinement of this list of key waste properties is expected, however, as more testing data become available. A comparison of the expected waste properties with the recommended simulant properties shows that, in many cases, the simulant properties are in the range expected for the waste. In other cases, there are not sufficient waste 
characterization data to make a meaningful comparison. Some of the key points of the simulant vs. waste comparisons are summarized below.

Characterization data show that the shear strength of the recommended wet sludge simulant (66\% kaolin clay in water) falls within the range expected for wet tank sludge. Further, the simulant density is representative of that measured for samples taken from the waste tanks. Particle size analyses of both sludge samples and the simulant show similar average sizes and distributions. The qualitative descriptions of sludge samples also is consistent with the behavior of the $66 \%$ kaolin clay sludge simulant (e.g., "The solids were sticky...").

No quantitative physical property characterization data are available for samples of hardpan or dried tank sludge. There are, however, indirect indications of some of the hardpan strength properties. For example, previous sluicing campaigns were incapable of dislodging the hardpan wastes, and samples of the hardpan are said to have the consistency of "blackboard chalk." Based on this information, an estimated range for hardpan mechanical strength was developed. The recommended simulants fall within this range. It is expected that the hardpan/dried sludge simulant strengths will need to be refined, once the needed physical property characterization data are available.

The recommended hardpan/dried sludge simulants are not appreciably soluble. It is known that the retrieval of at least some of the hardpan wastes is improved when a low-ionic-strength sluice fluid is used. This implies that dissolution is a significant retrieval mechanism for some hardpan wastes. It is not expected, however, that all dried sludge will be appreciably soluble. ${ }^{(a)}$ The recommended hardpan/dried sludge simulants (kaolin/plaster) do not presume waste solubility, so the performance of dissolution-based waste-retrieval processes against these simulants is likely to be worse than would be expected if the processes were applied to actual waste.

Mechanical strength measurements made using chemically based hard saltcake simulants were used as the basis for selecting the target compressive strength of the hard saltcake simulants. No such measurements have been made using actual saltcake samples, but the selected target strengths are consistent with qualitative descriptions of the hard saltcake strength (e.g., "concrete-like" [Wong 1990]). Similarly, the target strengths of the soft saltcake simulants are consistent with the "soft snow cone" descriptions given for samples of soft saltcake.

Dissolution rate data indicate that the K-Mag hard saltcake simulants dissolve more slowly than the rate expected for the actual hard saltcake. For this reason, the hard saltcake simulants (KMag) might not be appropriate for testing dissolution-based retrieval methods. Predicted hard saltcake-retrieval rates for dissolution-based retrieval methods, based on the testing of K-Mag simulants, will likely be much lower than the actual rates. The porosity of the soft saltcake simulants (rock salt/plaster) is much higher than that expected for hard saltcake, so the soft saltcake simulants

\footnotetext{
(a) This assumes that the mechanism for dried sludge strength development is primarily the heat-induced chemical reaction of sludge particles at their contact points. This process is analogous to the sintering of ceramics at high temperature, with the exception that the reaction of sludge particles takes place at lower temperatures and requires much more time to affect the bulk strength significantly. Dried sludge may owe some of its strength to interstitial salt crystals. In such a case, dissolution effects may be an important part of the retrieval process.
} 
are probably not useful for predicting the dissolution rates of hard saltcake. The development of appropriately soluble hard-waste simulants is a continuing effort.

The rock salt/plaster simulants for soft saltcake appear to approximate the dissolution characteristics of soft saltcake reasonably. Uncertainties in the saltcake porosity and morphology prevent accurate, quantitative comparisons of simulant and saltcake dissolution rates, but dissolutionrate testing for various salts supports the validity of the rock salt/plaster simulants.

The validity of all of the simulants recommended in this report will not be established until test data generated using these simulants can be compared with actual waste-retrieval data. Until such a comparison can be made, simulant validation efforts will be limited to indirect comparisons, which entail some level of uncertainty. The continuous reduction of this uncertainty and its concomitant risk is the goal of the continuing simulant-development work. 


\subsection{References}

Aagaard, P. and H. C. Helgeson. 1982. "Thermodynamic and Kinetic Constraints on Reaction Rates Among Minerals and aqueous Solutions. I. Theoretical Considerations." American Journal of Science 282:237-285.

Golcar, G. R., J. G. Darab, M. R. Powell, P. A. Simith, J. Zhang, and J. Bontha. 1996. Retrieval Process Development and Evaluation Project FY95 Simulant Development Technology Task Progress Report. PNL-11103. Pacific Northwest Laboratory, Richland, Washington 99352.

Helgeson, H. C., W. M. Murphy, and P. Aagaard. 1984. "Thermodynamic and Kinetic Constraints on Reaction Rates Among Minerals and Aqueous Solutions. II. Rate Constants, Effective Surface Area, and the Hydrolysis of Feldspar." Geochimica et Cosmochimica Acta 48:2405-2432.

Krieg, S. A. 1992. A Description of the Hanford Single-Shell Tanks and Their Contents. WHC-SDTD-TI-001, Rev. 0. Westinghouse Hanford Company, Richland, Washington 99352.

Kupfer, M. J. 1981. Preparation of Nonradioactive Substitutes for Radioactive Wastes. DOE Research and Development Report prepared by Rockwell Hanford Operations, Richland, Washington. Report No. DOE/ET/41900-8.

Powell, M. R., C. M. Gates, C. R. Hymas, M.. A. Sprecher, N. J. Morter. 1995. Fiscal Year 1994 1/25-Scale Sludge Mobilization Testing. PNL-10582. Pacific Northwest Laboratory, Richland, Washington 99352.

Rodenhizer, D. G. 1987. Hanford Waste Tank Sluicing History. Westinghouse Report No. WHCSD-WM-TI-302, Rev. 0. Westinghouse Hanford Company, Richland, Washington 99352.

Sohnel, O. and P. Novotny. 1985. Densities of Aqueous Solutions of Inorganic Substances. Elsevier. New York.

Summers, D. A. 1995. Waterjetting Technology. E\&FN Spon, an imprint of Chapman \& Hall, London.

Wanner, D. D. 1993. 'Justification of Saltcake Simulants. WHC-SD-WM-TI-545, Rev. 0.

Westinghouse Hanford Company, Richland, Washington 99352.

Willingham, C. E. 1994. Thermophysical Properties of Hanford High-Level Tank Wastes. PNL9419. Pacific Northwest Laboratory, Richland, Washington 99352.

Wong, J. J. 1990. Document for Single Shell Tank Waste Simulant. WHC-SD-ER-TI-002, Rev. 0. Westinghouse Hanford Company, Richland, Washington 99352. 
